\title{
Clinical characteristics of sleep bruxism patients with idiopathic facial pain
}

\author{
Yangho Myung†, Jeong-II Seo†, Bok Eum Kim, Young Gun Kim, Seong Taek Kim* \\ Department of Orofacial Pain and Oral Medicine, Yonsei University College of Dentistry, Seoul, Republic of Korea
}

Purpose: To profile various clinical characteristics of sleep bruxism (SB) patients with idiopathic facial pain (IFP) in the orofacial region. Materials and Methods: We analyzed 28 SB patients among 210 patients with IFP complaints. The profiles were evaluated using patient charts including gender, age, pain duration, pain location, pain intensity and affected areas by pain. Results: SB with IFP occurred more often in females (85.7\%) than males (14.3\%). The mean age at presentation was 48.9 years. The most common IFP sites of SB patients were the right maxilla (28.6\%) and the right mandible (25.0\%). The pain complaints occurred mostly in 2 teeth or areas $(50.0 \%)$, followed by 1 area $(28.6 \%)$ and then in $\geq 3$ teeth or areas $(21.4 \%)$. The mean pain intensity was 5.9 on a visual analogue scale from 0 to 10 . The pain was spontaneous in 20 patients (71.4\%), and the mean pain duration was 24.4 months. Conclusion: Identification of clinical characteristics of SB patients with IFP could be useful in the diagnosis of various IFP patients and beneficial in decreasing unnecessary care to reduce IFP. Further studies with larger number of subjects and extended duration are required for more systemized diagnostic methods and development of future treatment guidelines. (J Dent Rehabil Appl Sci $2021 ; 37(2): 81-7)$

Key words: sleep bruxism; facial pain; idiopathic facial pain; headache

\section{Introduction}

Sleep bruxism (SB) is considered an oral parafunction characterized by involuntary grinding and clenching of the teeth. ${ }^{1}$ The prevalence of bruxism was estimated at $17 \%$ in children, $8 \%$ in middle-aged adults, and $3 \%$ in elderly individuals. ${ }^{2} \mathrm{SB}$ is classified as a sleep-related movement disorder (included in the International Classification of Sleep Disorders, ICSD-III version of 2014) that can be highly distressing because of several harmful consequences to the stomatognathic system, including tooth damage, headaches and muscle pain. Orofacial pain is reported in $66 \%$ to $84 \%$ of patients with SB. ${ }^{3}$

*Correspondence to: Seong Taek Kim

Professor, Department of Orofacial Pain and Oral Medicine, Yonsei University College of Dentistry, Yonsei-ro 50-1, Seodaemun-gu, Seoul, 03722, Republic of Korea Tel: +82-2-2228-3110, Fax: +82-2-393-5673, E-mail: k8756050@yuhs.ac

Received: March 17, 2021/Last Revision: April 6, 2021/Accepted: April 30, 2021

† These authors contributed equally to this work.
Idiopathic facial pain (IFP) is a type of heterotopic pain that includes projected nerve pain felt throughout the peripheral distribution of the affected nerve (e.g. TN, cluster headache, post herpetic neuralgia etc.) and referred pain perceived as a toothache as a result of convergence and central sensitization (e.g. myofascial, sinus, or cardiac pain, etc.). ${ }^{1}$ The prevalence of IFP in dental clinics is reported at 2.1\%, with a mean pain duration of 33 months. ${ }^{4}$ In a previous study of patients who visited a dental clinic, $88 \%$ had sought care for toothache, 3\% for IFP, and 9\% for a mixed condition of odontogenic and IFP. ${ }^{5}$ IFP in the dentoalveolar region has 4 potential sources including musculoskeletal pain, neuropathic pain,

Copyright@ 2021 The Korean Academy of Stomatognathic Function and Occlusion. (c) It is identical to Creative Commons Non-Commercial License. 
neurovascular pain, or remote pathology with referring pain to the dentoalveolar region. ${ }^{6}$ Examples of such pathology include sinus diseases, brain tumor, angina, throat cancer, as well as salivary gland and craniofacial vascular disorders. ${ }^{6}$

In a previous study, IFP was reported in $66 \%$ to $84 \%$ of patients with $\mathrm{SB} .{ }^{3}$ However, the presence or intensity of pain is not directly correlated with the frequency of rhythmic masticatory muscle activity (RMMA) episodes. ${ }^{7} \mathrm{SB}$ patients with a low frequency of RMMA (2 - 4 episodes per hour of sleep) have higher risks for orofacial pain and headache than SB patients with a high frequency of RMMA ( $>4$ episodes per hour of sleep). ${ }^{8} \mathrm{SB}$ may coexist with waketime tooth clenching and other oral parafunctions (e.g., lip, cheek, or nail biting), which can also cause or contribute to the development and persistence of orofacial pain.

SB patients often suffer from chronic facial pain for extended periods and receive unnecessary treatment repeatedly when their symptoms fail to improve. The purpose of this study was to profile SB patients with IFP in orofacial region, in order to identify their general characteristics.

\section{Materials and Methods}

The study subjects comprised $28 \mathrm{SB}$ patients among 210 patients with IFP complaints (a painful condition that occurs in the absence of any clinically evident cause in the teeth or periodontal tissues) who were admitted to the department of orofacial pain and oral medicine in dental hospital between May 2003 and April 2013.

$\mathrm{SB}$ was assessed by clinical examination and the following question: 'Have you been told, or did you notice yourself, that you grind your teeth or clench your jaws when you are asleep?' (Yes, no, unknown). The clinical examination included the observation of abnormal tooth wear, masticatory muscle hypertrophy, muscle tenderness, and signs and symptoms related to eventually concomitant disorders (e.g., pain and headache).

Methods for IFP diagnosis included diagnostic anesthesia, brain computerized tomography (CT), mag- netic resonance imaging (MRI), and diagnostic oral appliance. Diagnostic anesthesia was conducted with topical anesthesia and infiltration and the visual analogue scale (VAS) to measure pain was used before and after anesthesia.

\section{Patients chart review}

This study was undertaken with the approval of Institutional Review Board of the Dental Hospital (IRB number: 2-2015-0036). Gender, age, pain intensity, spontaneity of pain, referred pain, pain duration, pain location, and areas affected by pain were reviewed using patient charts. Data related to diagnoses and treatments were also investigated through chart review. Treatment methods included medication, physical therapy, oral appliance and trigger point injection. Frequency and effects of each treatment method were also evaluated. Trigger point injections were delivered using $0.5 \%$ procaine and $1 \%$ lidocaine. In addition, prescribed medications including anticonvulsant, anxiolytics, antidepressant, non-steroidal anti-inflammatory drug (NSAIDs) and muscle relaxant were reviewed.

\section{Results}

The common diagnosis of 210 IFP patients were neuropathic pain $(53.8 \%, \mathrm{n}=113)$ followed by myofascial pain (MFP) $(23.3 \%, \mathrm{n}=49), \mathrm{SB}(13.3 \%, \mathrm{n}$ $=28)$, psychological pain $(2.9 \%, \mathrm{n}=6)$, maxillary sinusitis and rhinitis $(2.9 \%, \mathrm{n}=6)$, migraine $(2.4 \%, \mathrm{n}$ $=5)$, and oral tumor $(1.4 \%, \mathrm{n}=3)$ (Fig. 1).

\section{Patient chart review and questionnaire survey}

A total of $28 \mathrm{SB}$ patients were analyzed in this study. The various chief complaints included lowor high-intensity pain of posterior teeth or areas, uncomfortable/unusual bite, morning stiffness, pain at mastication etc. $\mathrm{SB}$ was more common in females (female:male $=85.7 \%: 14.3 \%)$. The mean age of patients was 48.9 years. In terms of pain intensity of SB, $71.4 \%$ patients reported moderate pain, $14.3 \%$ mild pain and $7.1 \%$ severe pain. Compared to all IFP 


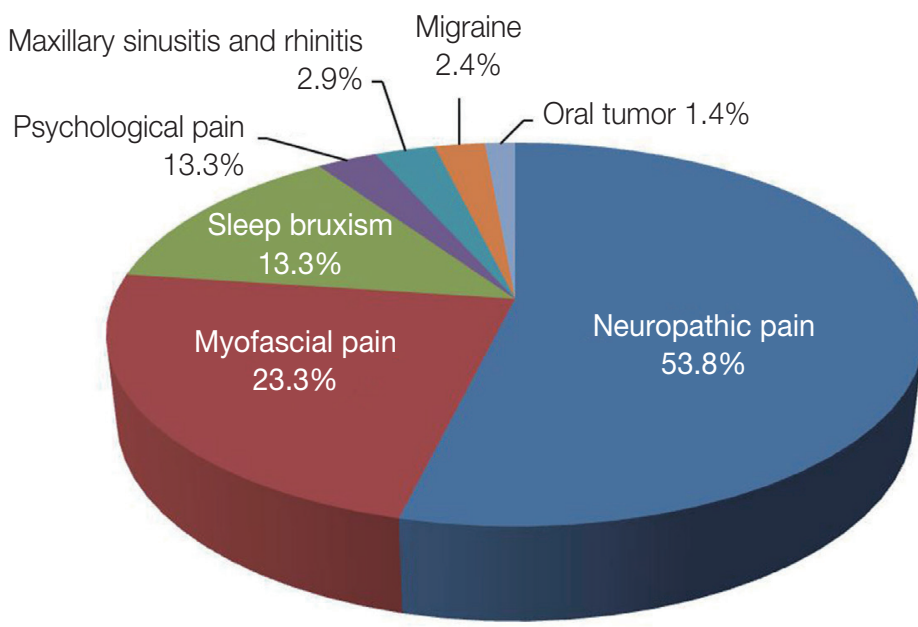

Fig. 1. Diagnoses of idiopathic facial pain (IFP) patients who visited the orofacial pain clinic $(n=210)$. patients, patients with severe pain were significantly lower in SB patients. The mean pain intensity was 5.9 on the VAS. Spontaneous pain was reported in $71.4 \%$ $(\mathrm{n}=20)$ and 1 patient reported pain referral (Table 1).

Most commonly affected areas were right maxilla $(28.6 \%)$ and right mandible (25.0\%) (Fig. 2). Compared to all IFP patients, the affected areas were almost evenly distributed in SB patients. SB complaints occurred mostly in 2 teeth or areas ( $\mathrm{n}=14,50.0 \%)$, followed by 1 area $(28.6 \%)$ and then in $\geq 3$ teeth or areas $(21.4 \%)$. Bilateral facial pain in the subgroup of pain complaints was experienced in 4 people $(14.3 \%$, IFP with SB) and 16 people (8.8\%, IFP without SB) (Table 1).

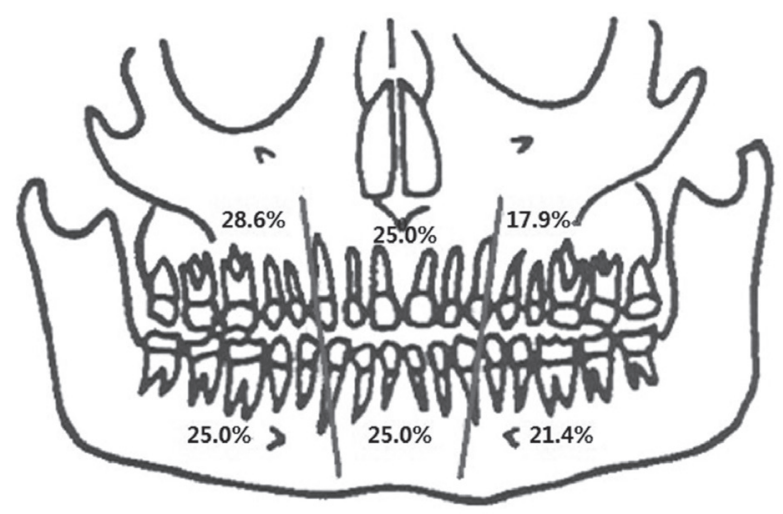

Fig. 2. Distribution of intraoral pain locations of $S B$ patients. 51.5\% patients reported pain in the maxilla and $48.5 \%$ reported pain in the mandible. Thirteen patients $(42.4 \%)$ had pain in both the maxilla and the mandible. Five patients had pain in $>1$ area, one area of the jaw.
Table 1. Characteristics of idiopathic facial pain (IFP) patients with sleep bruxism (SB) compared to IFP without SB patients

\begin{tabular}{lcc}
\hline \multicolumn{1}{c}{ Characteristics } & $\begin{array}{c}\text { IFP with } \\
\text { SB (28) }\end{array}$ & $\begin{array}{c}\text { IFP without } \\
\text { SB (182) }\end{array}$ \\
\hline Gender (male/female) & $14.3 \%(4) /$ & $26.9 \%(49) /$ \\
& $85.7 \%(24)$ & $73.1 \%(133)$ \\
Age (years) ${ }^{\dagger}$ & $48.9(19$ to 73$)$ & $49(15$ to 85$)$ \\
Pain Intensity & & \\
$\quad$ Mild & $14.3 \%(4)$ & $10.4 \%(19)$ \\
$\quad$ Moderate & $71.4(20)$ & $48.9 \%(89)$ \\
$\quad$ Severe & $7.1 \%(2)$ & $26.9 \%(49)$ \\
Spontaneous Pain & $71.4 \%(20)$ & $62.6 \%(114)$ \\
Referred Pain & $3.6 \%(1)$ & $8.8 \%(16)$
\end{tabular}

Pain Duration (months) ${ }^{\dagger} 24.4$ (3 to 120) 32.1 (3 to 360)

Pain Location*

$\begin{array}{lrr}\text {-Left Maxilla } & 17.9 \%(5) & 31.9 \%(58) \\ \text {-Middle Maxilla } & 25.0 \%(7) & 7.1 \%(13) \\ \text {-Right Maxilla } & 28.6 \%(8) & 27.5 \%(50) \\ \text {-Left Mandible } & 21.4 \%(6) & 26.4 \%(48) \\ \text {-Middle Mandible } & 25.0 \%(7) & 12.1 \%(22) \\ \text {-Right Mandible } & 25.0 \%(7) & 25.3 \%(46) \\ \text {-TMJ } & 17.9 \%(5) & 5.5 \%(10) \\ \text {-Buccal Cheek } & 7.1 \%(2) & 10.4 \%(19) \\ \text {-Lip } & 7.1 \%(2) & 6.0 \%(11)\end{array}$

Number of Affected Areas

\begin{tabular}{llr}
-One & $28.6 \%(8)$ & $45.1 \%(82)$ \\
-Two & $50.0 \%(14)$ & $39.6 \%(72)$ \\
-Three or more & $21.4 \%(6)$ & $13.2 \%(24)$ \\
Bilateral Facial Pain & $14.3 \%(4)$ & $8.8 \%(16)$ \\
\hline
\end{tabular}

† Mean (range).

* Permission of repetition. 


\section{Review of diagnosis and treatment methods}

Diagnostic methods conducted by the Department of Orofacial Pain and Oral Medicine included diagnostic anesthesia $(92.6 \%, \mathrm{n}=26)$, diagnostic oral appliance $(50.0 \%, \mathrm{n}=14)$, brain CT scan $(10.7 \%, \mathrm{n}=3)$ and MRI $(3.6 \%, \mathrm{n}=1)$ (Table 2).

In terms of treatment modality, patients were prescribed medication $(75.0 \%, \mathrm{n}=21)$, oral appliance $(60.7 \%, \mathrm{n}=17)$, physical therapy $(53.6 \%, \mathrm{n}=15)$, trigger point injection $(3.6 \%, \mathrm{n}=1)$ and botulinum toxin injection $(3.6 \%, \mathrm{n}=1)$. Compared to all IFP patients, the rate of oral appliance was significantly higher in SB patients as the most common option for

Table 2. Diagnostic methods were used in orofacial pain clinic*

\begin{tabular}{lcc}
\hline \multicolumn{1}{c}{ Characteristics } & $\begin{array}{c}\text { IFP with } \\
\text { SB (28) }\end{array}$ & $\begin{array}{c}\text { IFP without } \\
\text { SB (182) }\end{array}$ \\
\hline Diagnostic anesthesia & $92.6 \%(26)$ & $92.9 \%(169)$ \\
Diagnostic oral appliance & $50.0 \%(14)$ & $7.7 \%(14)$ \\
Brain CT & $10.7 \%(3)$ & $12.6 \%(23)$ \\
MRI & $3.6 \%(1)$ & $3.3 \%(6)$ \\
Waters' view & $0 \%(0)$ & $3.8 \%(7)$ \\
\hline
\end{tabular}

IFP, idiopathic facial pain; SB, sleep bruxism; CT, computerized tomography; MRI, magnetic resonance imaging.

* Permission of repetition.

Table 3. Treatment modalities in idiopathic facial pain (IFP) patients with sleep bruxism (SB) compared to IFP without $\mathrm{SB}$ patients

\begin{tabular}{lcc}
\hline \multicolumn{1}{c}{ Characteristics } & $\begin{array}{c}\text { IFP with } \\
\text { SB (28) }\end{array}$ & $\begin{array}{c}\text { IFP without } \\
\text { SB (182) }\end{array}$ \\
\hline Treatment* & & \\
Medicationt & $75.0 \%(21)$ & $97.3 \%(177)$ \\
Oral appliance & $60.7 \%(17)$ & $8.8 \%(16)$ \\
Physical therapy & $53.6 \%(15)$ & $18.7 \%(34)$ \\
Trigger point injection & $3.6 \%(1)$ & $8.6 \%(18)$ \\
Botulinum toxin injection & $3.6 \%(1)$ & $0.5 \%(1)$ \\
Treatment Duration (months) $¥ 9.1(1$ to 68$)$ & $6.3(1$ to 60) \\
\hline
\end{tabular}

* Permission of repetition.

† Anticonvulsant, anxiolytics, antidepressant, NSAID, muscle relaxant, topical Capsaicin, and other medications used.

$\ddagger$ Mean (range).
SB in dental clinics. Treatment duration ranged from 1 month to 5.7 years, with an average of 9.1 months (Table 3).

The prescribed medications included muscle relaxants $(36.2 \%, \mathrm{n}=17)$, NSAIDs $(25.8 \%, \mathrm{n}=12)$, antidepressants $(21.39 \%, \mathrm{n}=10)$, anticonvulsants $(8.5 \%$, $\mathrm{n}=4)$, and anxiolytics $(6.4 \%, \mathrm{n}=3)$ (Fig. 3). The 3 common drugs used for treatment of SB with IFP included cyclobenzaprine $\mathrm{HCl}$ (12.8\%), eperisone $\mathrm{HCl}(12.8 \%)$ and nortriptyline. (12.8\%) These medications are usually prescribed for relaxation of masticatory muscles in orofacial pain clinics.

\section{Discussion}

Neuropathic pain (53.8\%), MFP (23.3\%) and SB $(13 \%)$ were the 3 common diagnoses of IFP, which is higher than the previously reported $23.5 \%$ neuropathic pain. ${ }^{8}$

Comparison of the anterior vs. posterior teeth of the commonly affected areas indicated that IFP without $\mathrm{SB}$ more frequently involved the posterior than anterior teeth, whereas, the anterior and posterior teeth were similarly affected in SB. In terms of the number of affected areas in SB patients, $50.0 \%(\mathrm{n}=$ 14) of patients complained of symptoms in 2 teeth or areas, followed by $28.6 \%(\mathrm{n}=8)$ in 1 tooth or area and $21.4 \%(n=6)$ in $\geq 3$ teeth or areas. This may be

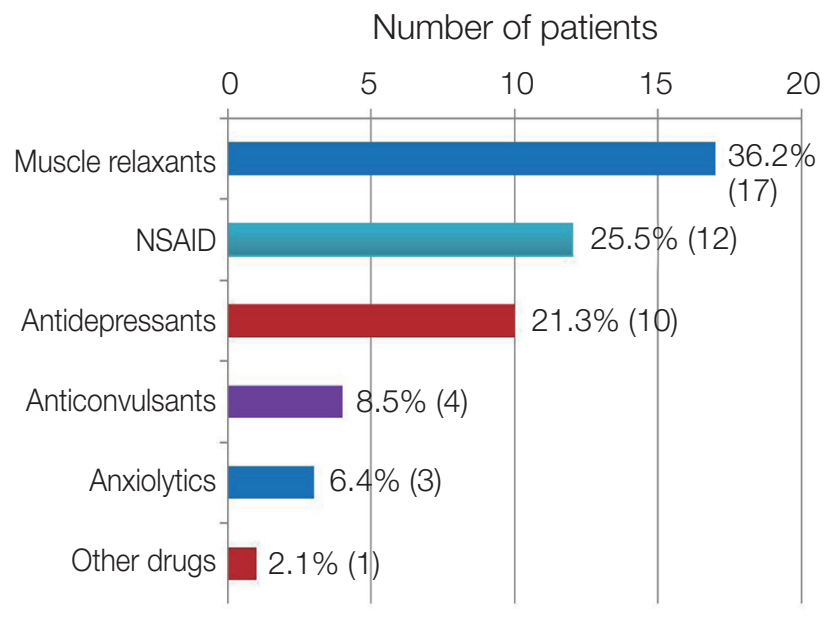

Fig. 3. Drugs administered for sleep bruxism (SB) patients with idiopathic facial pain (IFP) (Permission of repetition). 
due to excessive movement of the overall muscles during SB. Repeated and sustained masticatory muscle activity during sleep may has several potential clinical consequences, such as tooth wear, tooth damage, muscle fatigue, orofacial pain, and headache.,10

Our study results corroborate the previously reported clinical presentations of bilateral facial pain and headache $(84.3 \%)$ and frontotemporal location (67.1\%) in SB patients with pain. ${ }^{11,12}$ The commonest pain quality was tightness/pressure and its mean VAS intensity was $4.33{ }^{3}$ In the present study, pain intensity, was somewhat higher $\mathrm{r}$, with a mean VAS intensity of 5.9 and $71.4 \%$ of patients reporting moderate pain, $14.3 \%$ mild pain and $7.1 \%$ severe pain. The mean pain duration (24.4 months) of SB was less than the mean pain duration (31 months) of IFP without SB.

Consistent with the study by List et al., ${ }^{13}$ infiltration anesthesia reduced pain more than topical anesthesia, though the degree of response varied by patient. Pain derived from the pulp, i.e., from the tooth itself, requires anesthesia of the nerves of affected teeth, as such pain does not decrease with topical anesthesia alone. Continuous pain of the teeth or gums that is responsive to local anesthetics is often found to be neuropathic pain was often. In the current study, anesthesia was the most commonly used diagnostic method. These results indicate that diagnostic anesthesia is an effective and relatively simple diagnostic method that can be performed at the chair-side and satisfactory for differential diagnosis of IFP.

Of the many treatments that have been tested for SB management (e.g., behavioral modifications, oral appliances, medications), behavioral modifications (soft food diet, resting of the jaw, self-massage, etc.) and physical therapy (stretching exercises, massage, thermotherapy, and posture correction) are effective against pain due to myofascial problems of SB. ${ }^{1}$

Occlusal splints, either on the maxillary or the mandibular arch, have been extensively used in clinical practice to protect dental surfaces and relax the masticatory muscles. Most studies show a decrease (40 - 50\%) in the RMMA index in the first period of treatment (2- 6 weeks), regardless of the type of occlusal splint. ${ }^{14,15}$ Occlusal and anterior tooth appliances (e.g., NTI) are also used in cases of SB comor- bid with orofacial pain and TMD to relieve muscle and joint pain. ${ }^{16}$ In the current study, the 17 patients $(60.7 \%)$ treated with oral appliance reported slight improvement of SB symptoms.

Several medications and drugs are associated with decreased or increased SB activity, supporting the probability of central mechanisms for SB genesis. ${ }^{17}$ In symptomatic and most severe patients, pharmacologic treatments should be considered as a shortterm therapy only. ${ }^{18}$ Antidepressant drugs are also recommended for $\mathrm{SB}$, as well as for chronic orofacial pain. Low doses of amitriptyline (a tricyclic antidepressant) are ineffective against SB. ${ }^{19}$ In the current study, medical treatment for SB patients included muscle relaxants $(36.2 \%)$ and NSAIDs $(25.5 \%)$, for reduction of orofacial pain.

Whereas IFP patients are treated with several medications, SB patients are treated with oral appliance and physical therapy along with medication. The duration of treatment is longer for SB (9.1 months), as compared to IFP without SB (6.3 months). SB requires various treatments and long-term treatment periods, hence for suspected SB, patients are referred to either a pain specialist or the Department of Orofacial Pain and Oral Medicine.

\section{Conclusion}

The profiling of SB patients with IFP could be of use in the diagnosis of various IFP patients and beneficial in decreasing the number of unnecessary interventions performed to reduce IFP. Further studies with larger number of subjects and extended duration are required for more systemized diagnostic methods and development of future treatment guidelines.

\section{Acknowledgements}

This work was supported by the Korea Medical Device Development Fund grant funded by the Korea government (the Ministry of Science and ICT, the Ministry of Trade, Industry and Energy, the Ministry of Health \& Welfare, the Ministry of Food and Drug Safety) (Project Number: KMDF_PR_20200901_0109) 


\section{ORCID}

Yangho Myung https://orcid.org/0000-0002-0428-3496

Jeong-Il Seo https://orcid.org/0000-0001-7063-7312

Bok Eum Kim https://orcid.org/0000-0001-7396-2479

Young Gun Kim https://orcid.org/0000-0003-0989-4592

Seong Taek Kim https://orcid.org/0000-0001-9506-5103

\section{References}

1. de Leeuw R, Klasser GD. Orofacial pain: guidelines for assessment, diagnosis, and management. 5th ed. Chicago; Quintessence; 2013.

2. Carra MC, Huynh N, Lavigne G. Sleep bruxism: a comprehensive overview for the dental clinician interested in sleep medicine. Dent Clin North Am 2012;56:387-413.

3. Camparis CM, Siqueira JT. Sleep bruxism: clinical aspects and characteristics in patients with and without chronic orofacial pain. Oral Surg Oral Med Oral Pathol Oral Radiol Endod 2006;101:188-93.

4. Ram S, Teruel A, Kumar SK, Clark G. Clinical characteristics and diagnosis of atypical odontalgia: implications for dentists. J Am Dent Assoc 2009; 140:223-8.

5. Yatani H, Komiyama O, Matsuka Y, Wajima K, Muraoka W, Ikawa M, Sakamoto E, De Laat A, Heir GM. Systematic review and recommendations for nonodontogenic toothache. J Oral Rehabil 2014;41: 843-52.

6. Mattscheck D, Law AS, Nixdorf DR. Diagnosis of non-odontogenic toothache. In: Hargreaves KM, Cohen S, Berman LH, editors. Cohen's Pathways of the Pulp. 10th ed. St Louis; Mosby; 2011. p. 49-70.

7. Rompré PH, Daigle-Landry D, Guitard F, Montplaisir JY, Lavigne GJ. Identification of a sleep bruxism subgroup with a higher risk of pain. J Dent Res 2007;86:837-42.

8. Tomoyasu Y, Higuchi H, Mori M, Takaya K, Honda Y, Yamane A, Yabuki A, Hayashi T, Ishii-Maruyama M, Jinzenji A, Maeda S, Kohjitani A, Shimada M, Miyawaki T. Chronic orofacial pain in dental patients: retrospective investigation over 12 years. Acta Med Okayama 2014;68:269-75.

9. Carra MC, Huynh N, Morton P, Rompré PH, Pa- padakis A, Remise C, Lavigne GJ. Prevalence and risk factors of sleep bruxism and wake-time tooth clenching in a 7- to 17-yr-old population. Eur J Oral Sci 2011;119:386-94.

10. Vendrame M, Kaleyias J, Valencia I, Legido A, Kothare SV. Polysomnographic findings in children with headaches. Pediatr Neurol 2008;39:6-11.

11. Lobbezoo F, Lavigne GJ. Do bruxism and temporomandibular disorders have a cause-and-effect relationship? J Orofac Pain 1997;11:15-23.

12. Lobbezoo-Scholte AM, Lobbezoo F, Steenks MH, De Leeuw JR, Bosman F. Diagnostic subgroups of craniomandibular disorders. Part II: Symptom profiles. J Orofac Pain 1995;9:37-43.

13. List T, Leijon G, Helkimo M, Öster A, Svensson P. Effect of local anesthesia on atypical odontalgia-a randomized controlled trial. Pain 2006;122:306-14.

14. do Nascimento LL, Amorim CF, Giannasi LC, Oliveira CS, Nacif SR, de Moura Silva A, Nascimento DFF, Marchini L, de Oliveira LVF. Occlusal splint for sleep bruxism: an electromyographic associated to Helkimo Index evaluation. Sleep Breath 2008;12:275-80.

15. van der Zaag J, Lobbezoo F, Wicks DJ, Visscher CM, Hamburger HL, Naeije M. Controlled assessment of the efficacy of occlusal stabilization splints on sleep bruxism. J Orofac Pain 2005;19:151-8.

16. Jokstad A. The NTI-tss device may be used successfully in the management of bruxism and TMD. Evid Based Dent 2009;10:23.

17. Winocur E, Gavish A, Voikovitch M, Emodi-Perlman A, Eli I. Drugs and bruxism: a critical review. J Orofac Pain 2003;17:99-111.

18. Lavigne G, Manzini C, Huynh NT. Sleep bruxism. In: Kryger MH, Roth T, Dement WC, editors. Principles and practice of sleep medicine. 5th ed. St. Louis; Elsevier Saunders; 2011. p. 1129-39.

19. Raigrodski AJ, Christensen LV, Mohamed SE, Gardiner DM. The effect of four-week administration of amitriptyline on sleep bruxism. A double-blind crossover clinical study. Cranio 2001;19:21-5. 


\section{특발성 안면 통증 환자에서 수면 이갈이의 임상적 특징}

명양호† 대학원생, 서정일† 전문의, 김복음 전임의, 김영건 전문의, 김성택* 교수 연세대학교 치과대학 구강내과학교실

목적: 특발성 안면 통증 환자에서 수면 이갈이의 임상적 특징을 알아보기 위함이다.

연구 재료 및 방법: 특발성 안면 통증을 호소한 210 명의 환자 중 수면 이갈이가 존재하는 28 명의 환자의 성별, 나이, 통증 의 기간, 위치 및 강도, 통증에 영향을 받은 부위를 포함한 차트 분석을 시행하였다.

결과: 특발성 안면 통증이 있는 수면 이갈이 환자는 남성(14.3\%)보다 여성(85.7\%)이 많았다. 평균 연령은 48.9세였으며 가장 흔한 안면 통증 부위는 우측 상악 치아 $(28.6 \%)$ 와 하악 치아 $(25.0 \%)$ 부위였다. 2 개의 치아에 통증이 발생한 경우가 가장 많았으며 $(50.0 \%), 1$ 개 치아(28.6\%), 3개 치아 이상 $(21.4 \%)$ 순으로 통증이 나타났다. 평균 통증 강도는 visual analogue scale (범위: 0 - 10) 기준 5.9였다. 20명의 환자에서 통증은 자발통의 양상으로 나타났으며 $(71.4 \%)$, 평균 통증 기간 은 24.4 개월이었다.

결론: 특발성 안면 통증 환자에서 수면 이갈이가 있는 환자들의 임상적 특징은 다양한 특발성 안면 통증 환자의 진단에 유용할 수 있으며, 상기 통증을 줄이기 위해 시행하는 불필요한 치료를 감소시키는데도 효과적이다. 보다 체계화된 진단 방법 및 개발을 위한 치료 지침을 위해 후속 연구는 충분한 기간 및 다수의 환자를 대상으로 진행될 필요가 있을 것이다.

(구강회복응용과학지 2021;37(2):81-7)

주요어: 수면 이갈이; 안면통증; 특발성 안면통증; 두통

*교신저자: 김성택

(03722) 서울특별시 서대문구 연세로 50-1 연세대학교 치과대학병원 구강내과

Tel: 02-2228-3110 | Fax: 02-393-8076 | E-mail: k8756050@yuhs. ac 접수일: 2021년 3월 17일 | 수정일: 2021년 4월 6일 | 채택일: 2021년 4월 30일

† 명양호 저자와 서정일 저자는 본 논문에 동등하게 기여함. 